\title{
The effect of commercial enzyme preparation-assisted maceration on the yield, quality, and bioactivity of essential oil from waste carrot seeds (Daucus carota L.)
}

\author{
K. B. Śmigielski ${ }^{\mathrm{a}, \varpi}$, M. Majewska ${ }^{\mathrm{a}}$, A. Kunicka-Styczyńska ${ }^{\mathrm{b}}$, R. Gruska ${ }^{\mathrm{c}}$ and Ł. Stańczyk ${ }^{\mathrm{d}}$ \\ ${ }^{a}$ Institute of Food Chemistry \\ ${ }^{b}$ Institute of Fermentation Technology and Microbiology \\ ${ }^{c}$ Institute of Chemical Technology of Food \\ ${ }^{\mathrm{d}}$ Institute of Technical Biochemistry \\ Faculty of Biotechnology and Food Science, Lodz University of Technology, Stefanowskiego 4/10, 90-924 Lodz, Poland \\ Corresponding author: krzysztof.smigielski@p.lodz.pl
}

Submitted: 28 April 2014; Accepted: 17 June 2014

SUMMARY: Eight enzyme preparations were screened with a view to maximizing the yield of carrot seed essential oil. Three of the eight enzyme preparations investigated, lipase from Mucor circinelloides, XPect ${ }^{\circledR}$ pectinase, and Esperase ${ }^{\circledR}$ protease, significantly influenced the amount of essential oil obtained, with Esperase ${ }^{\circledR}$ being the most effective. The Taguchi method was applied to optimize the processing conditions for the Esperase ${ }^{\mathbb{B}}$ protease. Under the optimum conditions, the essential oil yield increased by approximately $48 \%$. The main constituent compounds in the oil are: carotol (OeA: 40.80\%-OeB: 46.17\%), daucol (OeA: 7.35\%-OeB: 6.22\%), sabinene (OeA: 5.12\%-OeB: 6.13\%), alpha-pinene (OeA: 4.24\%-OeB: 5.11\%) and geranyl acetate (OeA: $4.50 \%-\mathrm{OeB}: 3.68 \%$ ). As compared to the control sample, the essential oil obtained from enzyme-pretreated carrot seeds has the same biological activity against Bacillus subtilis and Candida sp., lower activity against Staphylococcus aureus, Escherichia coli, and Pseudomonas aeruginosa, and higher activity against Aspergillus niger and Penicillium expansum.

\section{KEYWORDS: Carrot; Enzyme preparation; Essential oil; Taguchi method}

RESUMEN: Efecto de la preparación mediante maceración con enzima asistida comercial sobre el rendimiento, la calidad, y la bioactividad de aceite esencial de residuos de semillas de zanahoria (Daucus carota L.). Ocho preparados enzimáticos fueron seleccionados con el fin de maximizar el rendimiento de aceites esenciales de semillas de zanahoria. Tres de los ocho preparados de las enzimas investigadas, lipasa de Mucor circinelloides, Xpect ${ }^{\mathbb{B}}$ pectinasa y Esperase ${ }^{\circledR}$ proteasa, influyeron de manera significativa sobre la cantidad de aceite esencial obtenido, siendo Esperase ${ }^{\circledR}$ el más eficaz. El método de Taguchi se aplicó para optimizar las condiciones del procesamiento para esta última. Bajo las condiciones óptimas, el rendimiento de los aceite esenciales aumentó aproximadamente un 48\%. Los principales compuestos constituyentes del aceite son: carotol (OEA: 40.80\%-OeB: 46,17\%), ducol (OEA: 7,35\%-OeB: 6,22\%), sabineno (OEA: 5,12\%-OeB: 6,13\%), alfa-pineno (OEA: 4,24\%OeB: $5,11 \%$ ) y acetato de geranilo (OEA: $4,50 \%-\mathrm{OeB}: 3,68 \%$ ). En comparación con la muestra control, el aceite esencial obtenido a partir de las semillas de zanahoria mediante enzima-pretratada tiene la misma actividad biológica frente a Bacillus subtilis y Candida sp., menor actividad frente a Staphylococcus aureus, Escherichia coli, y Pseudomonas aeruginosa, y una mayor actividad contra Aspergillus niger y Penicillium expansum.

PALABRAS CLAVE: Aceite esencial; Método Taguchi; Preparación enzimática; Zanahoria 


\begin{abstract}
Citation/Cómo citar este artículo: Śmigielski KB, Majewska M, Kunicka-Styczyńska A, Gruska R, Stańczyk $Ł$. 2014. The effect of commercial enzyme preparation-assisted maceration on the yield, quality, and bioactivity of essential oil from waste carrot seeds (Daucus carota L.). Grasas Aceites 65 (4): e047. doi: http://dx.doi.org/10.3989/ gya.0467141.
\end{abstract}

Copyright: (C) 2014 CSIC. This is an open-access article distributed under the terms of the Creative Commons Attribution-Non Commercial (by-nc) Spain 3.0 Licence.

\section{INTRODUCTION}

Essential oils are mixtures of volatile organic compounds obtained by steam distillation, hydrodistillation, or cold pressing. Along with their olfactory qualities, they also have some cytotoxic properties: antibacterial, antiviral, antifungal, insecticidal, and antiparasitic (Burt 2004), and sometimes even anticarcinogenic. They do not themselves carry a risk of genotoxicity, so they are safe for consumers (Bakkali et al., 2008). Because of these properties, essential oils are often used in perfumery, cosmetics, and food, and even in medicine and aromatherapy (Roldán-Gutiérrez et al., 2008).

An example of an essential oil with such a range of applications is carrot seed essential oil. It is used mainly in the food industry as a flavoring for soups, concentrates, grape wine, and nonalcoholic beverages, and also in the cosmetic and fragrance industry as a fixative (Saad et al., 1995; Surburg and Panten, 2006). It has fungicidal and antibacterial properties (Batt et al., 1983; Dwivedi et al., 1991; Giraud-Robert, 2005; Kilibarda et al., 1996; Staniszewska et al., 2005), and it has also been proven to be a hypotensive agent and a cardiac and central nervous system depressant (Saad et al., 1995).

Carrot seed essential oil is obtained by means of hydro-distillation of ground waste seeds. The extraction of this oil, similar to the extraction of essential oils from other plants with endogenous oil bodies, is often difficult as the structure of plant tissue inhibits the migration of the extractant (water) and the release of intracellular metabolites (Pinelo and Meyer, 2008). Due to these difficulties, new technologies are sought to improve the extraction process. Enzymes which catalyze the hydrolysis of glycosidic bonds in plants (mainly cellulases, hemicellulases, and pectinases) can be used for this purpose (Puri et al., 2012). It has been found that such enzymes, as well as proteinases, facilitate the release of bioactive compounds (Pinelo and Meyer, 2008), speed up extraction, and reduce the consumption of energy and extraction solvent (Puri et al., 2012), which makes the process environmentally friendly. For the same reasons, it is advisable to pretreat plant material with enzymatic hydrolysis prior to essential oil extraction.

This study presents a method of plant material pretreatment prior to hydro-distillation, leading to a higher yield of essential oil and reduced production costs. The experiment involved the pretreatment of waste carrot seeds (Daucus carota L.) var. Koral with commercial enzyme preparations.

\section{MATERIALS AND METHODS}

\subsection{Materials}

Waste carrot seeds which lost their ability to germinate were obtained from a local producer (W. Legutko Breeding and Seed Company, Wielkopolska, Poland).

Three lipases (Lipex ${ }^{\circledR}$ and two lipases produced by Rhizomucor miehei and Aspergillus niger), pectate lyase $\left(\mathrm{XPect}^{\circledR}\right)$, amylase $\left(\right.$ Stainzyme $\left.{ }^{\mathrm{B}}\right)$, cellulase $\left(\right.$ Celluclean ${ }^{\circledR}$ ), and serine protease (Esperase ${ }^{\circledR}$ ) (Novozymes, Bagsvaerd, Denmark) were donated by UNIVAR. The fourth, a noncommercial lipase, (specially prepared mycelium of Mucor circinelloides) was obtained from the Institute of Technical Biochemistry, Lodz University of Technology.

\subsection{Essential oil extraction}

\subsubsection{Seed preparation}

Carrot seeds (100.0 g) were ground in a buhr mill and homogenized in $450.0 \mathrm{~mL}$ of water at $20.0^{\circ} \mathrm{C}$ for $5.0 \mathrm{~min}$ using an MPW-324 homogenizer (Mechanika Precyzyjna, Warsaw, Poland).

\subsubsection{Enzymatic pretreatment}

a) Screening: Ground and homogenized seeds were subjected to the action of eight enzyme preparations at a concentration of $1.0 \mathrm{~g} \cdot 100.0 \mathrm{~g}^{-1}$ of seeds. The application of enzyme preparations was preceded by $\mathrm{pH}$ regulation in the appropriate range, as suggested by the manufacturer (Beckman $\Phi 71$, Beckman Instruments, Inc., 1981) using citric acid (70.0 g citric acid $100.0 \mathrm{~mL}^{-1}$ water). The slurry was then thoroughly shaken in a bioreactor (ReactorReady, Radleys equipped with a Heidolph RZR 2102 stirrer) for 18 hours, at the temperature suggested by the manufacturer.

b) Optimization: Ground and homogenized seeds were subjected to the action of Esperase ${ }^{\circledR}$ at a concentration of $0.5,1.0$, and $2.0 \mathrm{~mL} \cdot 100.0 \mathrm{~g}^{-1}$ of seeds. The application of the enzyme preparation was preceded by $\mathrm{pH}$ regulation in the range of 7.0-12.0 (Beckman $\Phi 71$, Beckman Instruments, Inc., 1981) using citric acid (70.0 g 
citric acid $100.0 \mathrm{~mL}^{-1}$ water). The slurry was then thoroughly shaken in a bioreactor (ReactorReady, Radleys equipped with a Heidolph RZR 2102 stirrer) at $25-45^{\circ} \mathrm{C}$ for $0.5-18$ hours (according to the Taguchi method).

c) Optimization: the actions undertaken were analogous to those from a), applying mutatis mutandis: enzyme preparation - Esperase $^{\circledR}$; Esperase $^{\circledR}$ concentration $0.5-2.0 \mathrm{~mL} \cdot 100.0 \mathrm{~g}^{-1}$ of seeds; $\mathrm{pH}$ range $7.0-12.0$, shaking conditions $25-45^{\circ} \mathrm{C}, 0.5-18$ hours.

\subsubsection{Hydro-distillation}

Plant material prepared according to step 2.2.1. (control sample - OeA) or 2.2.1.1. (OeB - sample pretreated with Esperase ${ }^{\circledR}$ ) was placed in a 2 L flask, to which $550.0 \mathrm{~mL}$ of water was added. Hydrodistillation was performed in triplicate for $5.0 \mathrm{~h}$ in a hydro-distillation apparatus providing very good separation of phases through an odorless operation (Śmigielski et al., 2009).

\subsection{Physicochemical properties of carrot seed essential oil}

The refractive index of the carrot seed essential oil obtained by hydro-distillation from the control and enzyme-pretreated carrot seeds was measured using an Abbemat refractometer (Dr. Kernchen); optical rotation was measured using an Autopol IV polarimeter (Rudolph Research).

\subsection{GC-MS analysis}

The equipment used in the study consisted of a Trace GC Ultra gas chromatograph coupled with a DSQ II mass spectrometer from Thermo Electron Corporation, an Rtx-1ms capillary column from Restek ( $60 \mathrm{~m}$ long, internal diameter of $0.25 \mathrm{~mm}$, film thickness of $0.25 \mu \mathrm{m})$. Signals from two detectors (FID, MS) were simultaneously collected using an MS-column flow splitter from SGE. The following parameters and conditions used were: programmed temperature $50-(3 \mathrm{~min})-300{ }^{\circ} \mathrm{C}(30 \mathrm{~min})$, temperature gradient $4{ }^{\circ} \mathrm{C} \cdot \mathrm{min}^{-1}$, injector temperature (SSL) $280{ }^{\circ} \mathrm{C}$, detector temperature (FID) $300^{\circ} \mathrm{C}$, carrier gas - helium, carrier gas flow rate at a constant pressure of $200 \mathrm{kPa}$, split of 1:20. The parameters of the mass spectrometer were as follows: ionization energy $70 \mathrm{eV}$, ion source temperature $200{ }^{\circ} \mathrm{C}$, full scan mode in the mass range of 33-420. The flavor compounds in carrot essential oil were identified by GC-MS according to the mass fragmentation pattern and spectral comparison with standards from the NIST, Wiley $8^{\text {th }}$ edition and Adams Libraries as well as by comparison of retention indices with data from the NIST, Wiley $8^{\text {th }}$ edition, Adams Libraries, and the Pherobase (http://www.pherobase.com/).

\subsection{Near-infrared spectroscopy}

The spectrophotometer used was an FT-IR Nicolet 6700; number of sample scans 32, collection length $15.76 \mathrm{sec}$, resolution 8.000 , levels of zero filling 1 , number of scan points 8480 , number of FFT points 16,384 , laser frequency $15,798.3 \mathrm{~cm}^{-1}$, interferogram peak position 4096, apodizationHapp-Genzel, phase correction-Mertz, number of background scans 32, background gain 1.0, wave range (wavenumber) $11,000-4000 \mathrm{~cm}^{-1}$, detectorInGaAs, beam splitter: $\mathrm{CaF}_{2}$, source-white light. The supplied software OMNIC and TQ Analyst were used for both the control of the spectrophotometer's work and the analysis of the obtained results.

\subsection{Assessment of the antimicrobial activity of the essential oil}

\subsubsection{Microorganism cultivation and inoculum preparation}

The following strains were used in the study: the Gram-positive bacteria Bacillus subtilis ATCC 6633 and Staphylococcus aureus ATCC 1803; the Gram-negative bacteria Escherichia coli ATCC 1627 and Pseudomonas aeruginosa ATCC 1555; the yeast Candida sp. LOCK 0008; and the molds $A$. niger LOCK 0436 and Penicillium expansum LOCK 0535. The microorganisms were obtained from the American Type Culture Collection ATCC and the Center of Industrial Microorganisms Collection of the Institute of Fermentation Technology and Microbiology, Lodz University of Technology, Poland, WDCM 105. The stock cultures of bacteria were maintained on Trypticase Soy Agar (TSA, Oxoid) slants, while those of the yeast and molds on Sabouraud Dextrose Agar (SDA, bioMerieux) slants at $4{ }^{\circ} \mathrm{C}$. Before each experiment, the strains were twice subcultured in Trypticase Soy Broth (TSB, Oxoid) and Sabouraud Dextrose Liquid Broth (SDLB, bioMerieux). Inoculated broths of $B$. subtilis were incubated at $30{ }^{\circ} \mathrm{C}$ for $24 \mathrm{~h}$, and those of E. coli, S. aureus, and P. aeruginosa at $37^{\circ} \mathrm{C}$ for $24 \mathrm{~h}$. Broths inoculated with yeast and molds were incubated at $25{ }^{\circ} \mathrm{C}$ for $24-72 \mathrm{~h}$. Freshly prepared slant cultures were used for the experiments. An inoculum of each strain was prepared in a standard saline solution $(0.85 \% \mathrm{NaCl})$ and adjusted to a final concentration of approximately $10^{7} \mathrm{CFU} \cdot \mathrm{mL}^{-1}$.

\subsubsection{Antimicrobial test conditions}

The antimicrobial activity of the essential oils was estimated by the impedimetric method using a Bactometer M64 (bioMerieux). The procedure was as follows: $0.1 \mathrm{~mL}$ of a standardized inoculum of the tested strain was placed in a Bactometer well containing a chemical agent at the tested concentration 
and a growth medium, adjusted to a final volume of $1 \mathrm{~mL}$. The essential oils were added in the concentration range of 50 to $400 \mu \mathrm{L} \cdot \mathrm{mL}^{-1}$ at $50 \mu \mathrm{L}$ increments for $P$. aeruginosa, from 1 to $15 \mu \mathrm{L} \cdot \mathrm{mL}^{-1}$ at $1 \mu \mathrm{L}$ increments for B. subtilis, $S$. aureus, $E$. coli, A. niger and $P$. expansum and from 0.1 to $1 \mu \mathrm{L} \cdot \mathrm{mL}^{-1}$ at 0.1 $\mu \mathrm{L}$ increments for Candida sp. B. subtilis, S. aureus, and $P$. aeruginosa strains were cultivated in GPM (General Purpose Medium) and the E. coli strain in EM (Entero Medium); yeast and molds were grown in YMM (Yeast Moulds Medium). GPM, EM, and YMM media are designated for the impedimetric evaluation of specified microorganisms by the manufacturer of the Bactometer, bioMerieux. Cell suspensions of $0.1 \mathrm{~mL}$ in $0.9 \mathrm{~mL}$ of the appropriate medium served as positive controls. Negative controls were bacteria and yeast $/ \mathrm{mold}$ cultures with $0.5 \mu \mathrm{g} \cdot \mathrm{mL}^{-1}$ of Novobiocin and $0.2 \mu \mathrm{g} \cdot \mathrm{mL}^{-1}$ of cycloheximide, respectively. The microorganisms were incubated for $72 \mathrm{~h}$ at their optimal growth temperatures as indicated above. After incubation in the Bactometer, each culture was checked for microorganism viability by streaking on Plate Count Agar (PCA, bioMerieux). Plates were incubated for $72 \mathrm{~h}$ for bacteria and $120 \mathrm{~h}$ for yeast and molds at the optimal growth temperatures of particular microorganisms.

Minimal inhibitory concentration (MIC) was calculated as the minimal concentration of a chemical agent inhibiting microbial growth in Bactometer wells (all microorganisms were grown on PCA plates simultaneously).

All experiments were conducted in triplicate.

\subsection{Sensory assessment}

Sensory assessment was based on a forced-choice test (Baryłko-Pikielna and Matuszewska, 2009). The respondents were asked to decide which of the coded essential oils (i.e., the essential oil from seeds pretreated with Esperase ${ }^{\circledR}$ or the essential oil from the control sample) was lighter and smelled more similar to the essential oil from carrot seeds obtained by another research team via the classical method. The analysis took place in a special sensory evaluation laboratory.

\subsection{Statistical evaluation}

\subsubsection{The Taguchi method}

The optimization of the enzymatic pretreatment of waste carrot seeds prior to hydro-distillation was performed according to the Taguchi experimental design approach, which allows for reducing costs and time consumption by evaluating several process factors at the same time with the smallest number of experimental runs based on a table known as the orthogonal array (Cukor et al., 2011; Chen et al., 2011; Tadayon et al., 2012; Benito-Román et al., 2011).
For the problem under consideration, a L9 orthogonal array (Statistica 7.0) was adopted, consisting of 9 systems. The following factors which may influence enzyme activity were identified as critical: enzyme preparation loading $\left(0.5 ; 1.0 ; 2.0 \mathrm{~mL} \cdot 100.0 \mathrm{~g}^{-1}\right.$ seed), time $(0.5 ; 2.0 ; 18.0 \mathrm{~h})$, solution $\mathrm{pH}(7.0$; $10.5 ; 12.0)$, and temperature $\left(25.0 ; 35.0 ; 45.0^{\circ} \mathrm{C}\right)$. The parameters of carrot seed enzymatic modification prior to hydro-distillation were optimized in terms of the levels of the above factors. The aim of optimization was to determine such levels of these factors that would ensure the highest efficiency of hydro-distillation, with oil yield chosen as the output factor. The study was randomized to avoid systematic errors and all the experiments were carried out in triplicate. The signal-to-noise ratio $(\mathrm{S} / \mathrm{N}$ ratio, Eta) was calculated from the experimental data using a loss function, which gave a function transforming repetitive data to other values and was used as a measure of the variation present in the experiment. The characteristics of the maximum desired value were adopted and optimization was done by calculating the $\mathrm{S} / \mathrm{N}$ ratio (Eta) (controllable factors/ confounders) according to the formula:

$$
\text { Eta }=-10 \cdot \log _{10}\left[(1 / \mathrm{n}) \cdot \Sigma\left(1 / \mathrm{y}_{\mathrm{i}}^{2}\right)\right]
$$

where $n$ is the number of iterations and $y_{i}$ is the value of the output variable (the yield of the isolated essential oil).

The theoretical amount of essential oil was calculated for the determined optimum process conditions on the basis of the expected $\mathrm{S} / \mathrm{N}$ ratio.

\section{RESULTS AND DISCUSSION}

\subsection{Selection of enzyme type}

The aim of this study was to develop an effective method of essential oil extraction which provides higher efficiency due to enzymatic hydrolysis. For this purpose, screening was performed on eight different enzyme preparations: four lipases (from $M$. circinelloides, $R$. miehei, and $A$. niger, as well as Lipex ${ }^{\circledR}$ ), which are thought to cleave ester bonds both in cuticle polyesters and cell membrane phospholipids, as well as glycosidic bonds in cell wall polysaccharides; two preparations which degrade the cell wall and its main components, cellulose and pectin: Celluclean classic ${ }^{\circledR}$ cellulase hydrolyzing $\beta$-1,4-glycosidic bonds in cellulose and XPect ${ }^{\circledR}$ pectinase hydrolyzing $\alpha-1-4$ linked polygalactosyluronic acid; Esperase ${ }^{\circledR}$ serine protease cleaving peptide bonds present in cell membrane proteins, and Stainzyme ${ }^{\mathbb{R}}$ amylase hydrolyzing endo-1,4 bonds in starch, both in amylose and amylopectin.

Carrot seeds were subjected to the action of these eight enzyme preparations at a concentration of $1.0 \mathrm{~g} \cdot 100.0 \mathrm{~g}^{-1}$ of seeds for 18 hours under 


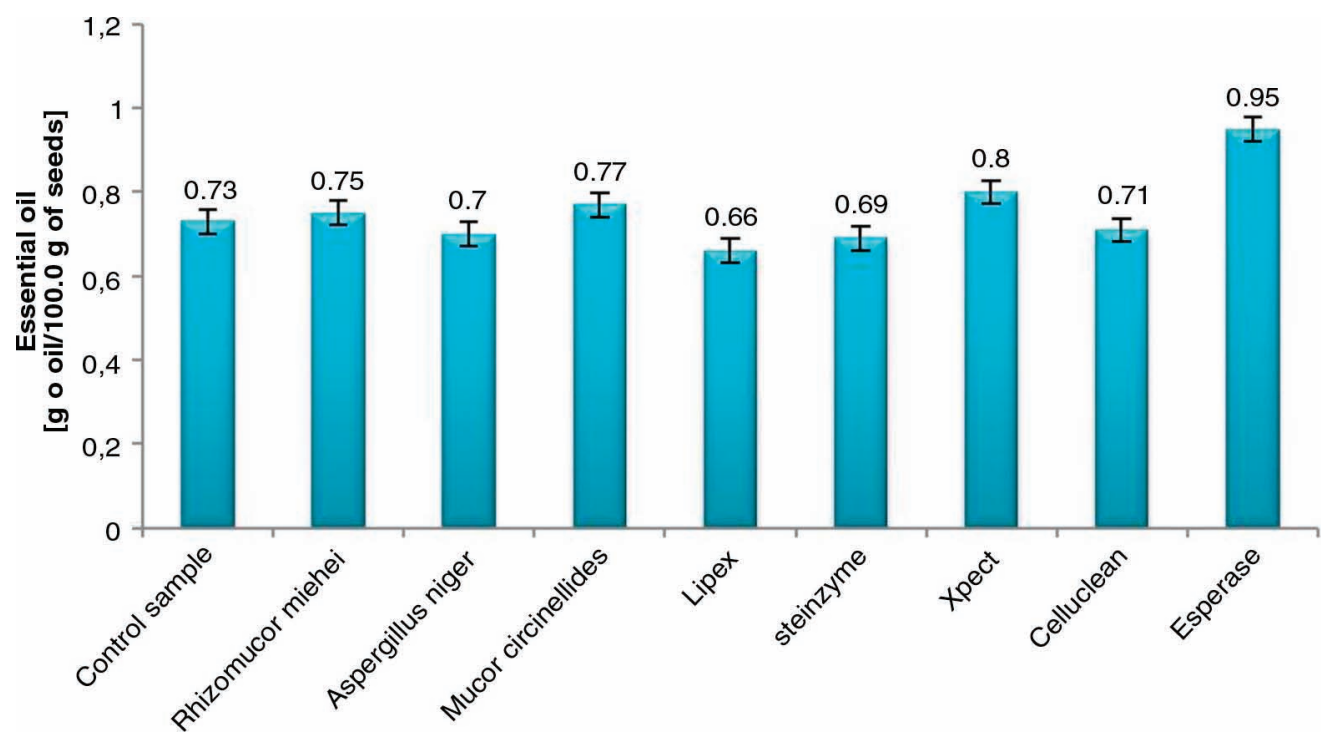

FIGURE 1. Efficiency of carrot seed essential oil extraction according to the enzyme preparation used.

conditions suggested by the manufacturer. The results of the screening are shown in Figure 1.

Only three of the eight enzyme preparations investigated, $M$. circinelloides lipase, XPect ${ }^{\circledR}$ pectinase, and Esperase ${ }^{\circledR}$ protease, significantly influenced the efficiency of the essential oil extraction. The highest yield, higher by nearly $30 \%$ than that of the control sample, was afforded by Esperase ${ }^{\circledR}$, so this preparation was chosen for further studies.

\subsection{Optimization of the process for enzyme-assisted hydro-distillation}

The selection of appropriate conditions to ensure the optimum activity of the enzyme preparations used for the treatment of plant material, is a key step because the effectiveness of enzymatic digestion influences the efficiency of essential oil extraction. The application of the Taguchi method for the optimization of enzymatic processing conditions considerably accelerated this step.

Following the results of preliminary screening, Esperase $^{\circledR}$ protease was investigated with a view to optimize its processing conditions. The results obtained from 9 experiments conducted in triplicate according to the $\mathrm{L}_{9}$ orthogonal array are presented in Table 1.

The ANOVA statistical analysis at a significance level of $p=0.05$ showed that all input factors influenced the yield of carrot seed essential oil, with $\mathrm{pH}$ being the most significant one (contribution of $44.83 \%$ ) (Table 2).

The results of the statistical analysis of the relationship between input factor levels and mean Eta values ( 3 replicates) are visually presented in Fig. 2. The optimum levels of input parameters adopted for enzyme-pretreated carrot seeds were as follows: time $2.0 \mathrm{~h}, \mathrm{pH} 10.5$, temperature $35^{\circ} \mathrm{C}$ and an enzyme preparation loading of $2.0 \mathrm{~mL} \cdot 100.0 \mathrm{~g}^{-1}$ of seeds.

The theoretical amount of $\mathrm{OeB}$ was calculated for the determined optimum process conditions on the basis of the expected $\mathrm{S} / \mathrm{N}$ ratio. The $\mathrm{S} / \mathrm{N}$ value under optimal conditions is 0.800612 , hence $\mathrm{y}_{\mathrm{i}}=1.096$ from equation (1).

To verify the optimum levels of input parameters, 3 experiments were performed, showing the yield of OeB $\left(1.08 \pm 0.004 \mathrm{~g} \cdot 100 \mathrm{~g}^{-1}\right)$ to be approximately $48 \%$ higher than that of $\mathrm{OeA}\left(0.73 \pm 0.001 \mathrm{~g} \cdot 100 \mathrm{~g}^{-1}\right)$.

\subsection{Physicochemical properties of carrot seed essential oils}

The specific rotation and refractive index of the obtained essential oils did differ significantly, according to the Mann-Whitney test. Essential oil from the control sample revealed a specific rotation of $-8.038 \pm 0.0453$ and a refractive index of $\mathrm{n}_{20}$ : 1.488635 , while the corresponding figures for the essential oil from enzyme-pretreated seeds were $-6.606 \pm 0.031$ and $\mathrm{n}_{20}^{\mathrm{D}}: 1.488982$, respectively. Commercially available essential oils from carrot seeds are not standardized in terms of refractive index and optical rotation, and there is little information about these parameters in the literature (Özcan and Chalchat, 2007; Pigulevskii and Kovaleva, 1955; Pigulevskii et al., 1965).

\subsection{Organoleptic observations}

Essential oil from the control sample was a clear, oily liquid, amber-yellow in color, characterized by a heavy herbal-earthy scent. 
6• K.B. Śmigielski, M. Majewska, A. Kunicka-Styczyńska, R. Gruska and Ł. Stańczyk

TABLE 1. Plan of optimization of carrot seed (Daucus carota L.) enzymatic modification prior to hydrodistillation by the Taguchi method; L9 orthogonal array - input factors and mean output factors

\begin{tabular}{lcccccc}
\hline No of tests & Time $[\mathbf{h}]$ & $\begin{array}{c}\text { Enz. prep. } \\
{\left[\mathbf{m L} \cdot \mathbf{1 0 0 . 0} \mathbf{g}^{-1} \mathbf{~ o f ~ s e e d s ] ~}\right.}\end{array}$ & $\begin{array}{c}\text { Temperature } \\
{\left[{ }^{\circ} \mathbf{C}\right]}\end{array}$ & $\mathbf{p H}$ & $\begin{array}{c}\text { Ess. oil obtained } \\
{\left[\mathbf{g} \cdot \mathbf{1 0 0 . 0} \mathbf{g}^{-1} \text { of seeds] }\right.}\end{array}$ & $\begin{array}{c}\text { S/N ratio } \\
{[\mathbf{E t a}]}\end{array}$ \\
\hline 1 & 0.5 & 1.0 & 35.0 & 10.5 & 0.94 & -0.57410 \\
2 & 18.0 & 2.0 & 45.0 & 10.5 & 0.83 & -1.58545 \\
3 & 2.0 & 2.0 & 25.0 & 10.5 & 1.01 & 0.08387 \\
4 & 18.0 & 0.5 & 25.0 & 12.0 & 0.73 & -2.77458 \\
5 & 0.5 & 1.0 & 45.0 & 12.0 & 0.99 & -0.05878 \\
6 & 0.5 & 2.0 & 25.0 & 7.0 & 0.70 & -3.09863 \\
7 & 18.0 & 0.5 & 35.0 & 7.0 & 0.79 & -2.08480 \\
8 & 2.0 & 0.5 & 35.0 & 12.0 & 0.89 & -0.98022 \\
9 & 2.0 & 1.0 & 45.0 & 7.0 & 0.77 & -2.23379 \\
\hline
\end{tabular}

TABLE 2. ANOVA analysis of statistical significance of input factors for enzymatic pretreatment of carrot seeds (Daucus carota L.) according to the Taguchi method

\begin{tabular}{lcccc}
\hline Input factor & Sum of squares SS & Fisher F criterion & p-Value & Contribution* [\%] \\
\hline $\mathrm{pH}$ & 14.84627 & 170.7958 & 0.000000 & 44.83 \\
Enz. prep. & 8.46981 & 97.4392 & 0.000000 & 25.58 \\
Time & 6.23699 & 71.7522 & 0.000000 & 18.84 \\
Temperature & 2.77789 & 31.9576 & 0.000001 & 8.39 \\
Residual & 0.78232 & & & 2.36 \\
\hline
\end{tabular}

*Contribution is defined as $100 \times$ (pooled sum of squares/total sum of squares).

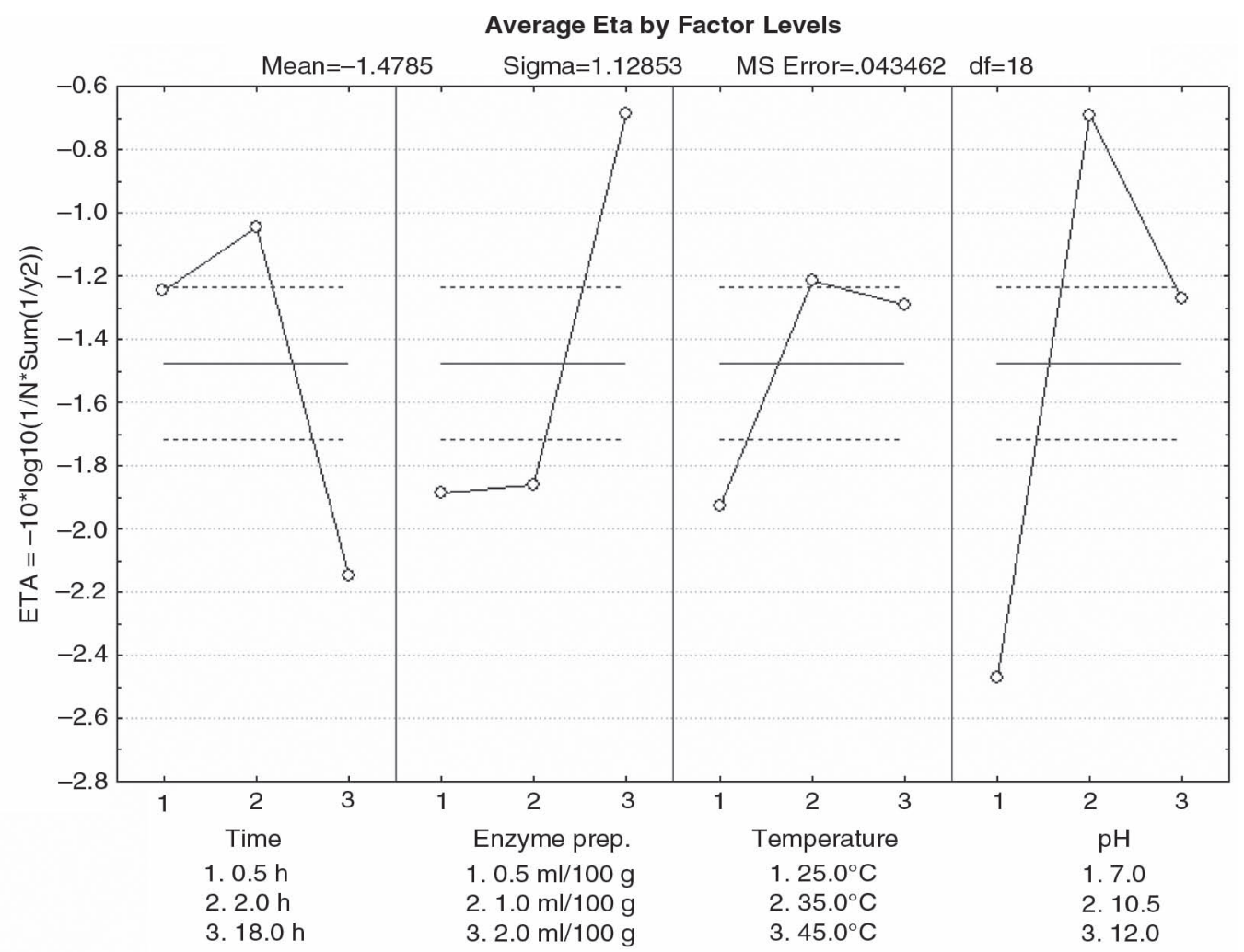

FIGURE 2. The effect of input factors in the process of enzymatic pretreatment of carrot seeds (Daucus carota $\mathrm{L}$.) on the $\mathrm{S} / \mathrm{N}$ ratio. 
Essential oil from enzymatically pretreated carrot seeds was slightly lighter. Its scent was characteristic of essential oils from this kind of plant material; however, a slightly sour note was present.

\subsection{Characterization of flavor compounds in carrot seed essential oils}

$75(\mathrm{OeB})$ to $86(\mathrm{OeA})$ chemical compounds were identified in the essential oils, which corresponded to $97.59 \%(\mathrm{OeA})$ and $98.95 \%(\mathrm{OeB})$ of their total composition. The composition of the essential oils was compared using a statistical tool (MannWhitney test) (StatSoft electronic manual, 2012, www.statsoft.com).

The content of the main compound, carotol, differed among the essential oils and was significantly increased (by 13\%) by enzymatic hydrolysis (OeA: 40.80-OeB: $46.17 \%$ ). The action of serine protease not only cleaves peptide bonds but also ester linkages (Topf et al., 2001), releasing carotol from its possible combinations with proteins. It is also possible that the degradation of protein quaternary structure increases the availability of carotol and facilitates its extraction.

Given that there was no other significant change in the concentration of oxygenated sesquiterpenes, this statistically significant increase in carotol content suggests that differences in the content of other compounds are likely to result from the enhanced extraction of this terpenoid, which changes the proportions in the chemical composition of the oil. Hence, a subsequent decrease in the percentage fractions of all analyzed groups of compounds (except for oxygenated sesquiterpenes) can be noted. Some statistically significant changes were observed for oxygenated monoterpenes: geraniol (OeA: 0.71-OeB: 0.42) and terpinen-4-ol (OeA: 0.95-OeB: 0.29); and sesquiterpenes: alpha-amorphene (OeA: 0.47-OeB: 0.22) and (Z)-beta-farnesene (OeA: 0.56-OeB: 0.47).

\subsection{Similarity of the oils as determined by NIRS analysis}

Near-infrared spectroscopy (NIRS) was applied to compare the essential oils OeA and OeB. Despite some differences observed in the composition of the essential oil from enzyme-pretreated carrot seeds, as revealed by the statistical analysis (Table 3 ), the high correlation coefficient obtained $(86.29 \%)$ indicates very high similarity of the quantitative contents of the main chemical compounds in the essential oils studied.

\subsection{Antimicrobial activity}

The antimicrobial activity of the essential oils derived from carrot seeds is shown in Table 4. Both essential oils showed significantly higher activity against the tested Gram-positive bacteria ( $B$. subtilis, $S$. aureus) than against Gram-negative bacteria (E. coli, P. aeruginosa), which is characteristic of all essential oils, possibly due to the existence of an outer membrane surrounding the cell walls of Gramnegative bacteria, limiting the diffusion of hydrophobic substances, such as oils, through the lipopolysaccharide layer of the wall (Burt, 2004).

The growth of Gram-positive bacteria was inhibited at concentrations of $2-5 \mu \mathrm{L} \cdot \mathrm{mL}^{-1}$, with the activity of OeB against $S$. aureus $\left(5 \mu \mathrm{L} \cdot \mathrm{mL}^{-1}\right)$ being lower than that of OeA $\left(2 \mu \mathrm{L} \cdot \mathrm{mL}^{-1}\right)$. The lower activity of OeB against bacteria in the genus Staphylococcus is associated with a significantly reduced content of camphene and linalool, which are compounds with high biostatic activity (Alma et al., 2004; Soković et al., 2010). Their reduced content may also lower the activity of the essential oil from carrot seeds pretreated with Esperase ${ }^{\circledR}$ against Gram-negative bacteria.

On the other hand, OeB showed greater antifungal activity than OeA, which may result from the increased amount of carotol, which is a potent fungicide (Abad et al., 2007) with an efficiency comparable to that of commercial agents such as Funaben $\mathrm{T}$ (Jasicka-Misiak et al., 2004), and limonene (Omran et al., 2011). The activity of OeB against both molds $\left(2 \mu \mathrm{L} \cdot \mathrm{mL}^{-1}\right)$ is 2.5 times greater than that of the control sample $\left(5 \mu \mathrm{L} \cdot \mathrm{mL}^{-1}\right)$, while the sensitivity of Candida sp. to the tested essential oils remains the same, and is the highest among all the tested microorganisms (MIC $0.6 \mu \mathrm{L} \cdot \mathrm{mL}^{-1}$ ).

These results show carrot seed essential oil to have good fungistatic activity against yeasts in the genus Candida and Gram-positive bacteria. Tavares and others (2008) and Maxia and others (2009) emphasized the antifungal properties of the essential oil obtained from the umbels of D. carota L. subsp. halophilus and D. carota L. subsp. carota, respectively.

\section{CONCLUSIONS}

It was proven that the use of $M$. circinelloides lipase, Xpect pectinase and Esperase ${ }^{\circledR}$ serine protease prior to the hydro-distillation of carrot seeds results in an increased efficiency of essential oil extraction, with the highest yield afforded by Esperase ${ }^{\circledR}$.

The optimal conditions for the enzymatic pretreatment of carrot seeds were selected by means of the Taguchi method. It was shown that the use of the enzyme preparation Esperase ${ }^{\circledR}$ to treat waste carrot seeds prior to hydro-distillation under the optimal conditions $\left(2.0 \mathrm{~h} ; \mathrm{pH} 10.5 ; 35^{\circ} \mathrm{C}\right.$; enzyme preparation loading of $2.0 \mathrm{~mL} \cdot 100.0 \mathrm{~g}^{-1}$ seeds) improves the diffusion of the extractant and increases the efficiency of essential oil extraction by $48 \%$. The presented method is free from defects typical of conventionally applied methods associated with insufficient degradation of plant tissue, which is especially 
8・K.B. Śmigielski, M. Majewska, A. Kunicka-Styczyńska, R. Gruska and Ł. Stańczyk

TABLE 3. Chemical composition of essential oils obtained from carrot seeds (Daucus carota $\mathrm{L}$.) OeA - essential oil from the control sample

OeB - essential oil from seeds pretreated with Protease ${ }^{\circledR}$

\begin{tabular}{|c|c|c|c|c|c|}
\hline No. & Compound & Content [\%] OeA & Content [\%] OeB & RI Rtx-1 & RI lit. Rtx-1 \\
\hline 1. & $\alpha$-Thujene* & 0.31 & 0.39 & 923 & 923 \\
\hline 2. & $\alpha$-Pinene* & 4.24 & 5.11 & 931 & 932 \\
\hline 3. & Camphene* & 0.39 & 0.41 & 943 & 944 \\
\hline 4. & Verbenene* & 0.10 & 0.08 & 946 & 944 \\
\hline 5. & Sabinene* & 5.12 & 6.13 & 966 & 966 \\
\hline 6. & $\beta$-Pinene & 1.51 & 1.45 & 970 & 971 \\
\hline 7. & 3-Methylnonane* & 0.08 & 0.00 & 971 & 970 \\
\hline 8. & $\beta$-Myrcene* & 0.42 & 0.35 & 983 & 981 \\
\hline 9. & Car-2-ene* & 0.14 & 0.05 & 1006 & 1008 \\
\hline 10. & p-Cymene* & 1.89 & 2.29 & 1012 & 1012 \\
\hline 11. & Limonene* & 0.64 & 0.45 & 1021 & 1022 \\
\hline 12. & $\beta$-Ocimene* & 0.05 & 0.00 & 1030 & 1034 \\
\hline 13. & $\gamma$-Terpinene* & 0.29 & 0.08 & 1049 & 1049 \\
\hline 14. & trans-Sabinene hydrate* & 0.18 & 0.37 & 1053 & 1053 \\
\hline 15. & trans-Linalool oxide* & 0.02 & 0.06 & 1058 & 1054 \\
\hline 16. & cis-Linalool oxide * & 0.01 & 0.09 & 1075 & 1078 \\
\hline 17. & $\alpha$-Terpinolene* & 0.04 & 0.00 & 1079 & 1080 \\
\hline 18. & cis-Sabinene hydrate $*$ & 0.14 & 0.34 & 1083 & 1083 \\
\hline 19. & Linalool* & 0.38 & 0.16 & 1085 & 1083 \\
\hline 20. & Thujol* & 0.16 & 0.32 & 1089 & 1095 \\
\hline 21. & Thujone* & 0.03 & 0.05 & 1097 & 1099 \\
\hline 22. & $\alpha$-Campholene aldehyde * & 0.09 & 0.11 & 1104 & 1103 \\
\hline 23. & Nopinone* & 0.10 & 0.14 & 1106 & 1110 \\
\hline 24. & trans-Pinocarveol* & 0.02 & 0.38 & 1122 & 1121 \\
\hline 25. & cis-Verbenol* & 0.41 & 0.00 & 1124 & 1127 \\
\hline 26. & Sabinene ketone* & 0.33 & 0.22 & 1127 & 1132 \\
\hline 27. & trans-Verbenol* & 1.67 & 1.83 & 1129 & 1128 \\
\hline 28. & Isopinocamphone* & 0.05 & 0.00 & 1136 & 1141 \\
\hline 29. & Pinocarvone* & 0.29 & 0.31 & 1139 & 1139 \\
\hline 31. & cis-Sabinol* & 0.13 & 0.06 & 1150 & 1147 \\
\hline 32. & p-Mentha-1,5-dien-8-ol* & 0.09 & 0.00 & 1147 & 1149 \\
\hline 33. & Terpinene-4-ol* & 0.95 & 0.29 & 1162 & 1162 \\
\hline & p-Cymene-8-ol* & 0.02 & 0.00 & 1164 & 1162 \\
\hline 35. & Myrtenal & 0.31 & 0.28 & 1171 & 1170 \\
\hline 36. & $\alpha$-Terpineol* & 0.12 & 0.06 & 1173 & 1175 \\
\hline & Verbenone* & 0.69 & 0.75 & 1179 & 1176 \\
\hline & Carveol* & 0.09 & 0.07 & 1201 & 1197 \\
\hline & Carvone* & 0.00 & 0.05 & 1231 & 1230 \\
\hline 40. & Cumin aldehyde* & 0.09 & 0.03 & 1240 & 1241 \\
\hline & Geraniol* & 0.71 & 0.42 & 1235 & 1239 \\
\hline & Bornyl acetate & 0.16 & 0.18 & 1267 & 1270 \\
\hline & Perillyl alcohol* & 0.00 & 0.09 & 1277 & 1278 \\
\hline & Carvacrol* & 0.06 & 0.00 & 1279 & 1278 \\
\hline & p-Cymenol* & 0.00 & 0.06 & 1286 & 1289 \\
\hline & p-Mentha-1,4-dien-7-ol* & 0.05 & 0.02 & 1312 & 1302 \\
\hline
\end{tabular}


TABle 3 (Continued)

\begin{tabular}{|c|c|c|c|c|c|}
\hline No. & Compound & Content [\%] OeA & Content [\%] OeB & RI Rtx-1 & RI lit. Rtx-1 \\
\hline 47. & $\gamma$-Terpinyl acetate & 0.06 & 0.06 & 1331 & 1333 \\
\hline 48. & Neryl acetate & 0.02 & 0.01 & 1340 & 1342 \\
\hline 49. & Geranyl acetate* & 4.50 & 3.68 & 1359 & 1361 \\
\hline 50. & Farnesyl acetate* & 0.17 & 0.00 & 1369 & 1370 \\
\hline 51. & Daucene & 1.61 & 1.79 & 1376 & 1377 \\
\hline 52. & $\beta$-Cubebene* & 0.18 & 0.00 & 1377 & 1372 \\
\hline 53. & $\beta$-Elemene* & 0.07 & 0.08 & 1384 & 1389 \\
\hline 54. & Sativene* & 0.02 & 0.04 & 1394 & 1396 \\
\hline 55. & cis- $\alpha$-Bergamotene* & 0.20 & 0.17 & 1408 & 1407 \\
\hline 56. & $\beta$-Caryophyllene* & 2.70 & 2.63 & 1414 & 1420 \\
\hline 57. & $\beta$-Cedrene* & 0.05 & 0.02 & 1423 & 1422 \\
\hline 58. & $\gamma$-Elemene* & 0.01 & 0.08 & 1430 & 1432 \\
\hline 59. & (Z)- $\beta$-Farnesene* & 0.57 & 0.47 & 1429 & 1434 \\
\hline 60. & $\beta$-Funebrene* & 0.08 & 0.02 & 1434 & 1431 \\
\hline 61. & (E)- $\beta$-Farnesene & 1.83 & 1.72 & 1444 & 1446 \\
\hline & $\alpha$-Humulene* & 0.13 & 0.00 & 1448 & 1448 \\
\hline & $\alpha$-Amorphene* & 0.12 & 0.00 & 1455 & 1457 \\
\hline 64. & $\gamma$-Muurolene* & 0.35 & 0.15 & 1469 & 1471 \\
\hline 65. & $\alpha$-Curcumene & 0.06 & 0.05 & 1468 & 1468 \\
\hline 66. & Germacrene D* & 0.03 & 0.39 & 1470 & 1468 \\
\hline & Dauca-5,8-dien* & 0.00 & 0.04 & 1471 & 1468 \\
\hline & $\beta$-Selinene* & 2.17 & 2.15 & 1479 & 1485 \\
\hline & $\alpha$-Selinene* & 0.33 & 0.00 & 1488 & 1490 \\
\hline 70. & $\alpha$-Himachalene* & 0.70 & 0.99 & 1490 & 1494 \\
\hline 71. & $\beta$-Bisabolene* & 1.49 & 1.22 & 1498 & 1502 \\
\hline 72. & $\gamma$-Cadinene* & 0.05 & 0.00 & 1505 & 1507 \\
\hline 73. & $\beta$-Sesquiphellandrene* & 0.24 & 0.19 & 1512 & 1516 \\
\hline & Calamene* & 0.01 & 0.00 & 1515 & 1517 \\
\hline 75. & $\alpha$-Chamigrene* & 0.09 & 0.11 & 1520 & 1526 \\
\hline 76. & $\alpha$-Bisabolene* & 0.25 & 0.05 & 1540 & 1534 \\
\hline 77. & Spathulenol* & 1.12 & 0.75 & 1546 & 1553 \\
\hline 78. & Caryophyllene oxide* & 4.18 & 3.95 & 1567 & 1551 \\
\hline 79. & Carotol* & 40.80 & 46.17 & 1589 & 1593 \\
\hline & Humulene epoxide II* & 0.61 & 0.36 & 1592 & 1602 \\
\hline & Cubenol* & 0.14 & 0.17 & 1601 & 1605 \\
\hline & Muurola-4,10(14)-dien-1-beta-ol* & 0.68 & 0.23 & 1617 & 1620 \\
\hline & Daucol* & 7.35 & 6.22 & 1620 & 1630 \\
\hline & $\alpha$-Cadinol* & 0.10 & 0.17 & 1632 & 1638 \\
\hline & Ledene oxide* & 0.17 & 0.20 & 1646 & 1646 \\
\hline & $\alpha$-Eudesmol* & 0.04 & 0.00 & 1649 & 1657 \\
\hline & $\beta$-Eudesmol* & 0.56 & 0.40 & 1651 & 1655 \\
\hline & Longifolenaldehyde* & 0.63 & 0.55 & 1657 & 1651 \\
\hline & $\alpha$-Bisabolol* & 0.00 & 0.11 & 1668 & 1670 \\
\hline 90. & Juniper camphor* & 0.39 & 0.35 & 1677 & 1682 \\
\hline 91. & $\alpha$-Cyperone & 0.16 & 0.18 & 1725 & 1727 \\
\hline
\end{tabular}


TABLE 3 (Continued)

\begin{tabular}{|c|c|c|c|c|c|}
\hline No. & Compound & Content [\%] OeA & Content [\%] OeB & RI Rtx-1 & RI lit. Rtx-1 \\
\hline & Total amount & 97.59 & 98.95 & & \\
\hline & Monoterpenes & 15.14 & 16.23 & & \\
\hline & Ox. Monoterpenes* & 12.09 & 10.54 & & \\
\hline & Sesquiterpenes* & 13.35 & 12.38 & & \\
\hline & Ox. Sesquiterpenes* & 56.93 & 59.80 & & \\
\hline
\end{tabular}

*Statistically significant differences (Mann-Whitney test; $p=0.05$ ).

TABLE 4. Antimicrobial activity of essential oils obtained from carrot seeds (Daucus carota L. $_{\text {. }}$ ) expressed as the minimal concentration of the oil inhibiting microbial growth (MIC) in $\mu \mathrm{L} \cdot \mathrm{mL}^{-\mathrm{i}}$ *

OeA - essential oil from the control sample

OeB - essential oil from seeds pretreated with Esperase ${ }^{\circledR}$

\begin{tabular}{|c|c|c|c|c|c|c|c|}
\hline \multirow[b]{2}{*}{ Essential oil } & \multicolumn{2}{|c|}{ Gram-positive bacteria } & \multicolumn{2}{|c|}{ Gram-negative bacteria } & \multirow{2}{*}{$\begin{array}{c}\text { Yeast } \\
\\
\text { Candida sp. } \\
\text { LOCK 0008 }\end{array}$} & \multicolumn{2}{|c|}{ Molds } \\
\hline & $\begin{array}{c}\text { Bacillus } \\
\text { subtilis } \\
\text { ATCC } 6633 \\
\end{array}$ & $\begin{array}{c}\text { Staphylococcus } \\
\text { aureus ATCC } \\
1803\end{array}$ & $\begin{array}{c}\text { Escherichia coli } \\
\text { ATCC } 1627\end{array}$ & $\begin{array}{c}\text { Pseudomonas } \\
\text { aeruginosa } \\
\text { ATCC 1555 }\end{array}$ & & $\begin{array}{c}\text { Aspergillus niger } \\
\text { LOCK } 0436\end{array}$ & $\begin{array}{c}\text { Penicillium } \\
\text { expansum } \\
\text { LOCK } 0535\end{array}$ \\
\hline OeA & 5 & 2 & 5 & 100 & 0.6 & 5 & 5 \\
\hline OeB & 5 & 5 & 10 & 250 & 0.6 & 2 & 2 \\
\hline
\end{tabular}

$* \mu \mathrm{L}$ of oil $\cdot \mathrm{mL}^{-1}$ of growth medium.

important in the case of raw materials that contain small amounts of oil or are not readily available. What needs to be emphasized is the fact that the content of carotol in the enzyme-pretreated essential oil is higher by $13 \%$ than in the control sample.

The essential oil obtained from enzymepretreated carrot seeds has good antifungal properties (with its activity against molds being 2.5 times higher than that of the control sample) and lower bacteriostatic activity against Gram-negative bacteria. Its qualitative composition is similar to that of the control sample, as confirmed by NIRS analysis (a correlation coefficient of $86.29 \%$ ); hence, it can be used in the food industry as a flavoring, and in pharmaceutical and cosmetic preparations.

\section{REFERENCES}

Abad MJ, Ansuategui M, Bermejo P. 2007. Active antifungal substances from natural sources. ARKIVOC 7, 116-145.

Alma MH, Nitz S, Kollmannsberger H, Digrak M, Efe FT, Yilmaz N. 2004. Chemical composition and antimicrobial activity of the essential oils from the gum of Turkish pistachio (Pistacia vera L.). J. Agric. Food Chem. 52, 3911-3914. http://dx.doi.org/10.1021/jf040014e.

Bakkali F, Averbeck S, Averbeck D, Idaomar M. 2008. Biological effects of essential oils - A review. Food Chem. Toxicol. 46, 446-475. http://dx.doi.org/10.1016/j.fct.2007.09.106.

Baryłko-Pikielna N, Matuszewska I. 2009. Sensoryczne badania żywności. Cracow: Wydawnictwo Naukowe PTTŻ.

Batt C, Solberg M, Ceponis M. 1983. Effect of volatile components of carrot seed oil on growth and aflatoxin production by Aspergillus parasiticus. J. Food Sci. 48, 762-768. http:// dx.doi.org/10.1111/j.1365-2621.1983.tb14893.x.

Benito-Román O, Alonso E, Lucas S. 2011. Optimization of the $\beta$-glucan extraction conditions from differentwaxy barley cultivars. J. Cereal Sci. 53, 271-276. http://dx.doi. org/10.1016/j.jcs.2011.01.003.

Burt S. 2004. Essential oils: their antibacterial properties and potential applications in foods - a review. Intern. J. Food Microbiol. 94, 223-253. http://dx.doi.org/10.1016/j. ijfoodmicro.2004.03.022.

Chen HH, Chung CC, Wang HY, Huang TC. 2011. Application of Taguchi method to optimize extracted ginger oil in different drying conditions. pp. 310-316. In: IPCBEE May 7-9; Bangkok. Singapoore: IACSIT Press (2011).

Cukor G, Jurković Z, Sekulić M. 2011. Rotatable central composite design of experiments versus Taguchi method in the optimization of turning. Metalurgija 50, 17-20.

Dwivedi SK, Pandey VN, Dubey NK. 1991. Effect of essential oils of some higher plants on Aspergillus flavus link infesting stored seeds of guar (Cyamopsis tetragonaloba $\mathrm{L}$.). Flavour Frag. J. 6, 295-297.

Giraud-Robert AM. 2005. The role of aromatherapy in the treatment of virial hepatitis. Int. J. Aromather. 15, 183-192. http://dx.doi.org/10.1016/j.ijat.2005.10.005.

Jasicka-Misiak I, Lipok J, Nowakowska EM, Wieczorek PP, Młynarz P, Kafarski P. 2004. Antifungal activity of the carrot seed oil and its major sesquiterpene compounds. Z. Naturfors. 59c, 791-796.

Kilibarda N, Nanusević N, Dogivić N, Ivanić R, Savin K. 1996. Content of the essential oil of the carrot and its antibacterial activity. Pharmacie 51, 777-778.

Maxia A, Marongiu B, Piras A, Porcedda S, Tuveri E, Gonçalves MJ, Cavaleiro C, Salgueiro L. 2009. Chemical characterization and biological activity of essential oils from Daucus carota L. subsp. carota growing wild on the Mediterranean coast and on the Atlantic coast. Fitoterapia 80, 57-61. http://dx.doi.org/10.1016/j.fitote. 2008.09.008.

Omran SM, Moodi MA, Amiri SMBNA, Mosavi SJ, Saeed SAMGM, Shiade SMJS, Kheradi E, Salehi M. 2011. The Effects of Limonene and Orange Peel Extracts on Some Spoilage Fungi. Int. J. Molec. Clin. Microbiol. 1, $82-86$.

Özcan MM, Chalchat JC. 2007. Chemical composition of carrot seeds (Daucus carota L.) cultivated in Turkey: 
characterization of the seed oil and essential oil. Grasas Aceites 5 (4), 359-365.

The Pherobase: Database of pheromones and semiochemicals [Internet]. Available from http://www.pherobase.com/ Accessed Mar. 11, 2014.

Pigulevskii GV, Kovaleva VI. 1955. Essentials oil of Carrot (Daucus carota L.). Trudy Botan, 5, 7-20.

Pigulevskii GV, Kovaleva VI, Motskus DV. 1965 Essential oils obtained from the fruit of the wild carrot Daucus carota L., collected in different regions. Rast Resursy $\mathbf{1}$, 227-230.

Pinelo M, Meyer AS. 2008. Enzyme-assisted extraction of antioxidants: release of phenols from vegetal Matrixes. J Env. Agricult. Food Chem. 7, 3217-3220.

Puri M, Sharma D, Barrow CJ. 2012. Enzyme-assisted extraction of bioactives from plants. Trends Biotechnol. 30, 37-44. http://dx.doi.org/10.1016/j.tibtech.2011.06.014.

Roldán-Gutiérrez JM, Ruiz-Jiménez J, Luque de Castro MD. 2008. Ultrasound-assisted dynamic extraction of valuable compounds from aromatic plants and flowers as compared with steam distillation and superheated liquid extraction. Talanta, 75, 1369-1375. http://dx.doi.org/10.1016/j. talanta.2008.01.057.

Saad H-EA, El-Sharkawy SH, Halim AF. 1995. Essential oils of Daucus carota L. spp. maximus. Pharm. Acta. Helv. 70, 79-84. http://dx.doi.org/10.1016/0031-6865(94)00054-Y

Soković M, Glamočlija J, Marin PD, Brkić D, van Griensven LJLD. 2010. Antibacterial effects of the essential oils of commonly consumed medicinal herbs using an in vitro model. Molecules, 15, 7532-7546. http://dx.doi.org/10.3390/ molecules 15117532 .

Staniszewska M, Kula J, Wieczorkiewicz M, Kusewicz D. 2005. Essential oil of cultivated carrots-the chemical composition and antimicrobial activity. J. Essent. Oil Res. 17, 579-583. http://dx.doi.org/10.1080/10412905.20 05.9699002 .

StatSoft: Electronic Manual online [Internet]. Available from https://www.statsoft.com/textbook/ Accessed Mar. 11, 2014.

Surburg H, Panten J. 2006. Common fragrance and flavor materials. Preparation, properties and uses. Wiley-VCH Verlag GmbH \& Co. KGaA, Weinheim, Germany.

Tadayon F, Motahar S, Hosseini M. 2012. Application of Taguchi method for optimizing the adsorption of lead ions on nanocomposite silica aerogel activated carbon. Acad. Res. Int. 2, 42-48.

Tavares AC, Gonçalves MJ, Cavaleiro C, Cruz MT, Lopes MC, Canhoto J, Ribeiro Salgueiro L. 2008. Essential oil of Daucus carota L. subsp. halophilus: Composition, antifungal activity and anti-inflammatory properties. J. Etnopharm. 130, 593-598. http://dx.doi.org/10.1016/j.jep.2010.05.054.

Topf M, Varnai P, Graham RW. 2001. QM/MM study of the deacylation step in elastase: Exploring active site dynamics and the effect of quantum region size. Abstr. Papers Am. Chem. Soc. 222 (1-2): Comp 061.

Śmigielski K, Raj A, Krosowiak K, Gruska R. 2009. Chemical composition of the essential oil of Lavandula angustifolia cultivated in Poland. J. Essenti. Oil Bear. Pl. 12 (3), 338347. http://dx.doi.org/10.1080/0972060X.2009.10643729. 